\title{
What Becomes of Practicum Enrollees?
}

\author{
EDWARD C. ROEBER \\ AND \\ JOSEPH A. JOHNSTON \\ University of Michigan
}

\section{Introduction}

Where do those who receive graduate degrees in guidance and counseling find employment? How many become school counselors? Are the school counselors the ones that showed promise during their supervised practicum work? To investigate such questions, a study of graduate students who had enrolled for supervised counseling in the Counseling Laboratory at the University of Michigan was undertaken in 1960, one to nine years after they had completed the practicum.

\section{Background and Methods}

The Counseling Laboratory in the School of Education, the University of Michigan, was established in 1953-54. Through the Summer Session of 1961, there were 746 graduate students under supervision at the Counseling Laboratory. Altogether they worked with over 4000 students, conducted in excess of 10,500 interviews and administered more than 25,100 tests of various types.

A follow-up questionnaire covered such areas as educational background, employment prior to and subsequent to enrollment, employment as of 1960-61, professional affiliation, future vocational plans, and an evaluation of the Laboratory experience. Beginning in September 1961, the questionnaire was sent to all enrollees whose addresses could be ascertained, and within one year $87 \%$ returned it. At least three postcards and a personal letter were used to motivate laggards. Because of the span of time needed to contact former enrollees, data from the study may have some imperfections, viz., a few of them who returned ques-

\footnotetext{
- 95 out of 746 enrollees were not included in the study. 36 were not included either because we knew they were deceased, living outside the U.S. or we had no mailing address, 59 were sent questionnaires and did not return them.
} 
tionnaires early may have changed their employment status later that year.

\section{Results}

Using the year of enrollment in the Laboratory as the base year for each student, employment records as given in the questionnaire were examined to find the job held (1) immediately prior to enrollment, (2) immediately subsequent to enrollment, and (3) in 1960-61. Often the subsequent job and the 1960-61 job were identical, especially for the more recent graduates who have only had one employer.

The classification of jobs was fourfold. The first group included those counseling in the elementary or secondary schools; the second

group, those doing counseling and related work in college or community agencies; the third group, those teaching in elementary or secondary schools, and a fourth group consisting of those neither counseling nor teaching.

Just prior to enrollment in the practicum a few more than one-third already held jobs in counseling. Forty-three percent were employed as teachers; twenty-two percent were neither in counseling nor teaching, but were homemakers, graduate students, people from business or industry or unemployed.

\section{Individuals Now Employed as Counselors In the Elementary or Secondary Schools}

One-third of the practicum enrollees are now doing counseling work in public or private schools (Table I, Group I). By far the majority ( 84 percent) of these people are working in Michigan even though one in four did their undergraduate work out of state. Most of this group (twothird) started their graduate work with a bachelors degree in the liberal arts while nearly all the others started with a degree in education. Of those from the liberal arts colleges, about one-half did their major work in either English or the social sciences.

The practicum is offered both during the academic year and the summer session. Those now counseling in the public schools did their work mostly during the summer session ( 70 percent).

\section{Individuals Now Employed in College Counseling or Personnel Work}

Counseling and related work in college or community agencies describes the present occupation of about one-fifth of the students who 


\section{TABLE I}

Positions Of $651^{*}$ Former Practicum Enrollees In Guidance And Counseling.

\begin{tabular}{|c|c|c|c|}
\hline & $\begin{array}{l}\text { Job Before } \\
\text { Enrollment }\end{array}$ & $\begin{array}{c}\text { Job After } \\
\text { Enrollment }\end{array}$ & $\begin{array}{c}\text { Job During } \\
\text { Academic Year } \\
1960-61\end{array}$ \\
\hline \multicolumn{4}{|l|}{ JOB CLASSIFICATION } \\
\hline $\begin{array}{l}\text { GROUP } 1 \text { - COUNSELING ( } N=214 \text { ) } \\
\text { Guidance work in public or private schools } \\
\text { (includes full \& part-time counseling, } \\
\text { guidance dir., dean and administration). }\end{array}$ & $22 \%(143)$ & $32 \%(210)$ & $33 \%(214)$ \\
\hline $\begin{array}{l}\text { GROUP II - COUNSELING ( } N=140) \\
\text { College counseling or personnel worker, } \\
\text { Psych. services, community \& agency } \\
\text { counseling. }\end{array}$ & $13 \% \quad(82)$ & $16 \%(105)$ & $22 \%(140)$ \\
\hline $\begin{array}{l}\text { GROUP III - TEACHING }(\mathrm{N}=216) \\
\text { Elementary or secondary }\end{array}$ & $43 \%(281)$ & $38 \%(248)$ & $33 \%(216)$ \\
\hline \multirow{2}{*}{$\begin{array}{l}\text { GROUP IV - OTHERS ( } \mathrm{N}=81 \text { ) } \\
\text { Graduate students, homemakers, business } \\
\text { and industry, misc., unemployed. }\end{array}$} & $22 \%(145)$ & $14 \% \quad(88)$ & $12 \% \quad(81)$ \\
\hline & $100 \%(651)$ & $100 \%(651)$ & $100 \%(651)$ \\
\hline
\end{tabular}

completed the practicum (Group II). They are mostly employed in Michigan. One in three did their undergraduate work out of state. Sixty percent had listed "counseling" as their vocational choice at the time they took the practicum. About one-half said they were not interested in a job change and most of those that were interested in a change, qualified it by saying that they would move for either betterment in salary or location. Only a few indicated dissatisfaction with their present position.

Comparing this group with the first, men outnumber women in both groups. The male-female ratio was 3 to 2 for the public school group and 2 to 1 for the college group as compared to an overall practicum ratio of 1 to 1 . Age and professional membership was almost identical for the two groups as was satisfaction with present job. While seventy percent of those in the public school group did their practicum work during the summer session, only forty percent from the college group enrolled during the summer. The other sixty percent did their practicum work during the academic year.

- This figure represents $87 \%$ of the practicum enrollees at the University of Michigan 1953-1961. Data comes from questionnaires collected over a period of one year and consequently does not necessarily reflect current status of those that returned their questionnaire early.

- Job during academic year, 1960-61, would be one to nine years after enrollment in the practicum. 


\section{Individuals Now Employed as Teachers In the Elementary or Secondary Schools}

One-third of the enrollees are now teachers in either elementary or secondary schools. However, this is probably not indicative of their ultimate vocational goal. When asked if they were interested in a change of position, almost one-half said "yes", and further indicated that they wanted to go into counseling. Only thirty percent said they were not interested in a change.

Comparing this group with those engaged in counseling (Groups I and II) shows some differences. This group has more women than the other groups. More go outside Michigan to find employment even though only one-third did their undergraduate work out of state. More had education as an undergraduate major ( 43 percent) and there was a slightly smaller proportion with any kind of professional affiliation. The time of enrollment for teachers was mostly during the summer (75 percent). Nearly three in four of all those that took the practicum and are now employed as counselors and teachers in public schools (Groups I and III), enrolled in the summer session.

\section{Individuals Now Neither Counseling Nor Teaching}

This group of enrollees included twelve percent of those who have taken the practicum. Of the twelve percent (Group IV, $N=81$ ) seventeen percent are still doing graduate work, thirty percent consider homemaking their present occupation and about the same percent are in business and industry. One-tenth of those in this group consider themselves unemployed and about the same proportion are in armed services or nursing. Members of this group, graduate students for example, may eventually work themselves into counseling.

The composition of this group is different in comparison to the other three. First, while the counseling groups (Groups I and II) had more men than women, this group has more women. While about one-half the women in all the other groups were married, nearly ninety percent in this group are married. It is a young group by comparison with the other three groups. Two-thirds are in a $21-40$ year bracket. One-fifth hold membership in a professional organization for counselors, and more than one-fifth indicated they were interested in a change of position. Finally, half of them took the practicum during the summer, the other half enrolled during the school year. 


\section{Practicum Ratings and Present Employment}

At the end of each semester or summer session, practicum supervisors rate all enrollees on the basis of their potential as counselors. While subjective, the ratings of those with the most and the least promise seem relatively easy to identify. The students are rated against other enrollees that session and, as far as possible, are then assigned one of five equal categories. (This forced division into fifths may be one of the weaknesses of the rating procedures.) The first two-fifths are considered "most promising", the last two-fifths are considered "least promising", and a middle fifth is equated as of "average promise". In Table II, the relationship between these ratings and present (1960-61) jobs indicate a few trends.

There was a tendency for more of those rated as "most promising" counselors to be employed in counseling than in teaching. The "least promising" ratings as a counselor were most prevalent for those now in teaching, although one in three of those now in counseling received "least promising" ratings. The best overall ratings were to those counseling in colleges or agencies (Group II), more than half of them received ratings of "most promising" and less than a third ratings of "least promising".

TABLE II

Supervisors' Ratings of Practicum Enrollees in Relation to the Enrollees' Job Classification in 1960-61

\begin{tabular}{|c|c|c|c|c|c|c|}
\hline & \multicolumn{6}{|c|}{ SUPERVISORS' RATINGS } \\
\hline & \multicolumn{2}{|c|}{$\begin{array}{c}\text { Most } \\
\text { Promising }\end{array}$} & \multirow{2}{*}{$\begin{array}{c}\text { Average } \\
\text { Promise } \\
3\end{array}$} & \multicolumn{2}{|c|}{$\begin{array}{c}\text { Least } \\
\text { Promising }\end{array}$} & \multirow{2}{*}{ Totals } \\
\hline & 1 & & & 4 & $5^{\circ}$ & \\
\hline \multicolumn{7}{|l|}{ JOB CLASSIFICATIONS } \\
\hline $\begin{array}{l}\text { GROUP I-COUNSELING ( } N=214 \text { ) } \\
\text { Guidance work in public or private scho } \\
\text { (Includes full and part-time counseling, } \\
\text { guidance director, dean and administrato }\end{array}$ & & $22 \%$ & $22 \%$ & $19 \%$ & $16 \%$ & $100 \%$ \\
\hline $\begin{array}{l}\text { GROUP II-COUNSELING ( } N=140) \\
\text { College counseling or personnel } \\
\text { worker, psych. services, } \\
\text { community \& agency counseling. }\end{array}$ & $28 \%$ & $23 \%$ & $20 \%$ & $14 \%$ & $15 \%$ & $100 \%$ \\
\hline $\begin{array}{l}\text { GROUP III - TEACHING ( } N=216) \\
\text { Elementary or secondary. }\end{array}$ & $12 \%$ & $18 \%$ & $25 \%$ & $27 \%$ & $18 \%$ & $100 \%$ \\
\hline $\begin{array}{l}\text { GROUP IV - OTHERS ( } N=81 \text { ) } \\
\text { Graduate students, homemakers, } \\
\text { business and industry, misc., } \\
\text { unemployed. }\end{array}$ & $27 \%$ & $19 \%$ & $20 \%$ & $14 \%$ & $20 \%$ & $100 \%$ \\
\hline
\end{tabular}

* The ratings are by fifths. A rating in either the first or second fifth meant the enrollee was considered "most promising" as a counselor. A rating in either the fourth or bottom fifth meant the enrollee was considered "least promising". Those in the middle fifth were considered to have "average promise" as counselors. 


\section{Conclusions}

Several observations seem warranted. Generally, the University of Michigan graduates in guidance and counseling find employment in either counseling or teaching. A large number of trained counselors are presently employed as teachers in the public schools. While this at first suggests an untapped source of counselor supply, it is conjectured that much of this source is not mobile. They are in teaching mainly because a suitable counseling position is not open at their present location or where they are willing or able to move. They may be more concerned with tenure or with a family than with a new career opportunity in a different location. Further, some may simply have decided that they prefer to teach. Practicum ratings of those now in teaching indicate that a number of them were not rated promising as counselors; they may well have found teaching more in line with their talents.

Practicum ratings indicate a significant trend for those rated as "most promising" to go into counseling work and a similar trend for the "least promising" to enter other fields. However, many, despite poor ratings as counselors in the practicum, persisted in finding employment as counselors in the schools. Poor evaluations stopped neither the counselor from seeking a counseling position nor the employer from hiring him. 